UDC 640.4:[658.3]:167.7

JEL Classification: M12

DOI: $10.15587 / 2706-5448.2021 .240230$

Article type «Reports on Research Projects»

\section{Iryna Segeda, Larysa Obolentseva, Svitlana Aleksandrova}

\title{
DEVELOPMENT OF A MODEL OF PERSONNEL MANAGEMENT IN THE HOTEL INDUSTRY
}

The object of this research is personnel management in the hotel industry. The paper considers theoretical and practical aspects of the features of phased personnel management in the hotel industry, taking into account the specifics of the industry. The importance of the attitude of each employee to their responsibilities and the company as a whole was emphasized, and it was established that the minimum number of employees can provide the highest quality of service. In any case, there is a need for effective personnel management, in the purposeful activities of the management of the organization to develop its own concept, strategy of personnel policy and management methods.

The main purpose of personnel management is formed. There are three groups of methods for personnel management, which almost completely reveal the step-by-step process of personnel management in the hotel industry. The necessity of application of complex technologies for achievement of more effective result is considered. A number of measures of nine stages of personnel management are prescribed.

Rational use of service personnel is a prerequisite that ensures the continuity and proper quality of the service process, and, as a consequence, the successful implementation of the production program of the hotel industry. The study of the main indicators of labor should begin with an assessment of the dynamics of the number of personnel of the enterprise, the intensity of its movement and structure over a period of three to five years.

Based on the study, a model of personnel management in the hotel industry, which determines the object and subject of management, their impact on each other, takes into account the stages of employee management. It will increase productivity, performance, organize work, monitor performance tasks, teamwork.

Keywords: personnel management, hotel management, stages of personnel management, personnel management system.

Segeda, I., Obolentseva, L., Aleksandrova, S. (2021). Development of a model of personnel management in the hotel industry. Technology Audit and Production Reserves, 5 (4 (61)), 15-18. doi: http://doi.org/10.15587/2706-5448.2021.240230

\section{Introduction}

The hotel industry belongs to the field of services, one of the main features of which is the direct interaction of employees of the hotel that provides services, with customers who receive them. Such interaction determines the increased role of the personnel management system for effective management of the hotel industry as a whole, while the main purpose of the entire personnel management system is to promote the successful achievement of the highest priority goals of the enterprise. The staff owned by the company is a significant part of its real capital. Thus, the issues affecting the personnel management system in the hotel industry at significant stages are urgent, because they depend on the success of the enterprise in conditions of fierce competition in the market of hotel services. The work of many scientists testifies to the importance of the question under study. Thus, the theoretical aspects of the formation and general management of personnel were studied by the authors of the research $[1,2]$. The papers [3-5] are devoted to the peculiarities of personnel management in the hotel industry. Given the existing developments in personnel management in the hotel industry, the authors believe that the development of a model of personnel management is inevitable.

Thus, the object of research was selected personnel management in the hotel industry. This was done on the example of one of the hotels in Kharkiv, Ukraine (Hotel N). The aim of research is to develop a model of phased personnel management in the hotel industry and identify recommendations for their improvement.

\section{Methods of research}

The hotel staff is the face of any service company, especially the hotel. Employees form the attitude of the client to the hotel no less than the interior of the room or the menu in the restaurant. Therefore, today the human factor in the hotel industry is given considerable attention. Every manager at a hotel company is aware of the importance 
of service personnel in ensuring the proper quality of work. The key to success is also that each employee feels part of the company, knows its main strategic objectives and financial condition.

There may not be many such employees in the hotel, although according to the recommendations of the World Tourism Organization, the optimal number of staff for 10 rooms in a three-star hotel should be 8 people, in a four-star - 12 people, in a five-star - 20 people [6]. Still, there is a need for effective personnel management, in the purposeful activities of the management of the organization to develop its own concept, personnel policy strategy and methods of human resource management.

The generalization of the experience of various world enterprises, presented in [7], allows to formulate the main purpose of personnel management, which is to provide personnel, organize their effective use, professional and social development, achieve mobility.

The science and practice of management distinguishes three groups of methods of personnel management of the enterprise: administrative, economic and socio-psychological $[5,8,9]$, which almost completely reveal the gradual process of personnel management. Such methods work in the hotel industry, given the specifics of services.

To use a special system of methods for a particular hotel business, it is necessary a tool of influence, management technology. Researchers examine of such technologies in $[10,11]$ makes it possible to divide them into several groups depending on the ultimate goal, scope of application or origin into traditional, industry, professional and innovative. The choice of a technology depends on the available resources and objectives of the enterprise. To achieve maximum efficiency, the use of several technologies at the same time is not excluded.

The personnel management system is a built-in part of the general management system of the hotel industry and its ultimate efficiency is determined by the results of the organization by following the main stages of personnel management (Fig. 1).

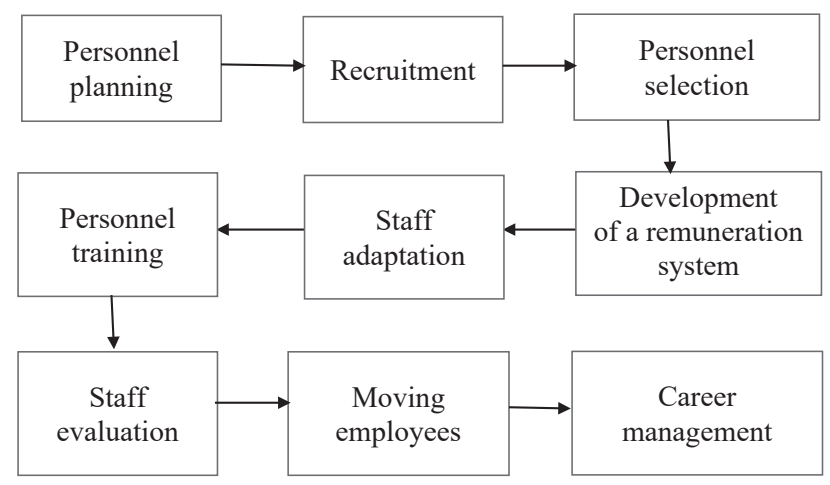

Fig. 1. The main stages of personnel management (formed by [12])

There are nine stages of personnel management, which include a number of measures [12]:

1) planning of human resources - this process consists of a series of sequential actions, during which analyze, forecast and calculate human resources, determine the needs for new staff. In addition, programs and action plans are drawn up;

2) recruitment - recruit (hire) staff, create a personnel reserve of potential candidates for all positions and positions. Then there is a constant modernization of the process of forming a personnel reserve in accordance with the requirements of the time;

3) selection of personnel - the search for an employee who is able to achieve the planned results. This stage of personnel management can be divided into several parts: the evaluation of job applicants and the selection of the best of the reserves that were created during the recruitment process. The main evaluation criteria include: a certain set of qualification and professional skills; personal and educational qualities and characteristics; previous work experience; compatibility with the environment. The main methods of selection include various types of tests and interviews, assessment of abilities and personal qualities;

4) development of the remuneration system - at this stage, salaries and benefits are calculated in order to attract and retain employees. It should not be forgotten that the salary is a monetary reward for the performance of duties and work performed. It is a crucial argument for most employees;

5) staff adaptation - the stage of adaptation of newly hired employees includes actions aimed at introducing new employees to the course of production life of the enterprise and all its departments and services. The newcomers are explained along the way what is expected of them, what kind of work in the company deserves to be rewarded. The main purpose of adaptation - to bring the knowledge, skills and abilities of the employee, existing experience and values in line with the values and traditions of the enterprise;

6) staff training - develop programs to train work skills for effective performance of future work. For example, industrial practice, development of new methods of work at trainings, seminars or conferences. Staff undergo retraining and training usually in the following cases:

- when a person comes to work in the organization;

- if the employee moves to a new position or the scope of authority of the employee changes;

- if the employee performs poorly the duties assigned to it, if the employee is found to have shortcomings; - when there is a change of equipment or technological processes;

- if new methods and developments are introduced;

7) personnel evaluation - the stage of analysis of labor activity, which includes the development of evaluation methods and bringing them to employees. Typically, the evaluation system includes modern and classical tools. This part of working with staff is considered the most time consuming. It requires the management of the organization to be highly qualified, because it is necessary not only to identify who the «weak link» is, but also to understand why the employee shows poor results;

8) relocation of employees - a stage associated with the increase, decrease, relocation, dismissal of staff;

9) career management - planning, organization, motivation and control of career growth of employees is performed in accordance with the goals, needs, capabilities of the enterprise.

An important feature of modern management is a comprehensive impact on all staff as a whole, which can be ensured only in the presence of such a model of personnel management, which will take into account the above stages of personnel management with the appropriate impact. 


\section{Research results and discussion}

Rational use of service personnel is a prerequisite that ensures the continuity and quality of the service process and the successful implementation of the production program of the hotel industry. The high culture of service in the field of hospitality depends on the organization of work and efficiency of use of working hours. The study of the main indicators of labor should begin with the dynamics of the enterprise. Initial indicators for calculations are given in Table 1, on the basis of which the average number of hotels for each period is calculated.

With regard to changes in staff dynamics, the following is observed: most employees are laid off voluntarily, and the trend of hiring new employees is significantly deteriorating every year.

Thus, in 2018, 9 new employees were hired, and in 2019 only 4, despite the fact that 18 people were fired. In 2020, two more new employees will appear and six will be laid off (Table 1).

Personnel dynamics of the three-star hotel $\mathrm{N}$

Table 1

\begin{tabular}{|l|c|c|c|}
\hline \multicolumn{1}{|c|}{ Indicators, persons } & 2018 year & 2019 yеаг & 2020 уеаг \\
\hline $\begin{array}{l}\text { Number of employees at the } \\
\text { beginning of the year }\end{array}$ & 57 & 55 & 44 \\
\hline Accepted & 9 & 4 & 2 \\
\hline Released, including & 11 & 18 & 6 \\
\hline Voluntarily & 4 & 14 & 2 \\
\hline $\begin{array}{l}\text { Number of employees at the } \\
\text { end of the year }\end{array}$ & 55 & 41 & 40 \\
\hline Average number & 56 & 48 & 42 \\
\hline
\end{tabular}

After calculating the average number and analyzing the main indicators of personnel dynamics, the coefficients of personnel movement intensity were determined (Fig. 2).

It is possible to see how the turnover rate decreases with each passing year, and how the coefficients of retirement and staff turnover increase.

Analysis of the personnel dynamics of Hotel $\mathrm{N}$ showed that more people are laid off than are employed.

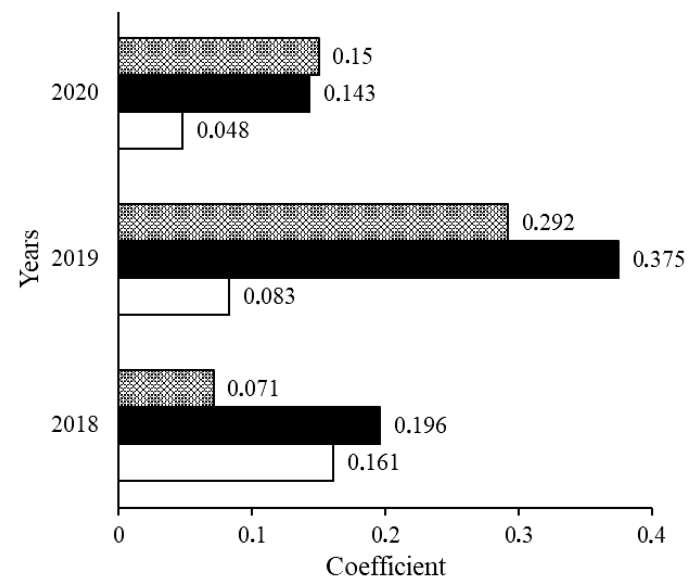

- Staff turnover ratio

- Staff turnover ratio on disposal

$\checkmark$ Turnover ratio by revenue

Fig. 2. Dynamics of changes in traffic intensity
Therefore, the calculation of the coefficients only confirmed this. The number of employees of the enterprise is constantly changing over time. The process of changing the number of employees, which leads to the redistribution of labor between individual enterprises, industries and regions is called the movement of labor, which occurs constantly.

The next step in the analysis of hotel staff is to study the composition and structure of the number of employees on various grounds: by gender, categories of employees (Table 2).

The staff structure of the hotel $\mathrm{N}$

Table 2

\begin{tabular}{|c|c|c|c|c|c|c|}
\hline \multirow[b]{2}{*}{ Characteristic } & \multicolumn{2}{|c|}{2018 уеаг } & \multicolumn{2}{|c|}{2019 уеаг } & \multicolumn{2}{|c|}{2020 уеаг } \\
\hline & $\begin{array}{l}\text { Per- } \\
\text { sons }\end{array}$ & $\%$ & $\begin{array}{l}\text { Per- } \\
\text { sons }\end{array}$ & $\%$ & $\begin{array}{l}\text { Рег- } \\
\text { sons }\end{array}$ & $\%$ \\
\hline Average number of employees & 56 & 100 & 48 & 100 & 42 & 100 \\
\hline \multicolumn{7}{|l|}{ 1. Grouping by sex: } \\
\hline men & 30 & 53.6 & 20 & 41.7 & 20 & 47.6 \\
\hline women & 26 & 46.4 & 28 & 58.3 & 22 & 52.4 \\
\hline \multicolumn{7}{|l|}{ 2. Grouping by professional groups: } \\
\hline leaders & 2 & 3.6 & 2 & 4.1 & 1 & 2.4 \\
\hline managers & 4 & 7.1 & 2 & 4.2 & 2 & 4.8 \\
\hline $\begin{array}{l}\text { others (maids, receptionists, porters, } \\
\text { cooks, waiters and other staff) }\end{array}$ & 50 & 89.3 & 44 & 91.7 & 39 & 92.8 \\
\hline
\end{tabular}

According to Table 2 it can be concluded that the hotel in 2019 and 2020 employed more women than men. Only in 2018, the number of men exceeds the number of women. That is, it shows that the hotel industry attracts more women than men.

Regarding the grouping by professional groups: the hotel has a tendency to reduce the number of middle and lower level employees. It can be assumed that employees are not satisfied with the management style of the hotel and, perhaps, the internal culture of the company and the still unfinished stages of personnel management.

\section{Conclusions}

Thus, analyzing the theoretical and practical part of the question studied, it is possible to draw the following conclusions.

Staff turnover is one of the key problems in personnel management of the hotel industry. In order to understand what exactly generates staff turnover, it is necessary to negotiate with the dismissed employees, with the head of the unit, on the basis of which to carry out «work on errors» in order to minimize losses in finding new employees and their training.

In order to «prevent» staff turnover, it is necessary to constantly ensure that employees receive any support and evaluation of their work from management in order to understand the employee's place in the hotel. It is not possible to forget about timely motivation in the form of additional payments or the possibility of career growth through experience, etc. 
And although money is not always the main reason to be dissatisfied with your work, in the end, it is the money factor that becomes decisive in making a decision.

In order to prevent conflicts with management due to late payment of wages in general or for overtime work, it is essential to evenly distribute work and pay among all employees, taking into account specific problems and all factors - from hotel profitability to employee personalities. This is the only way to offer people what they want and get quality service, speed and productivity in return. Based on the generalization of the scientific literature [13, 14] and the study, a model of personnel management in the hotel industry was built (Fig. 3).
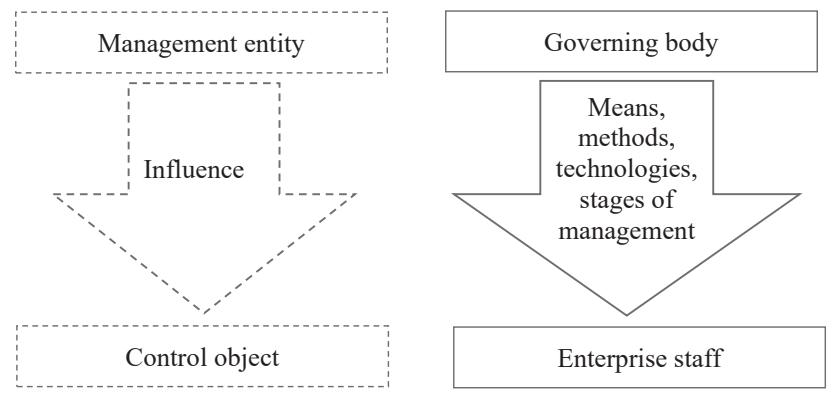

Fig. 3. Model of personnel management of the hotel enterprise

Along with the use of staff, it is advisable to follow the stages of employee management, which will increase productivity, performance, allow to organize work, monitor the implementation of tasks, work in a team. Therefore, the gradual management of personnel of hotel enterprises is appropriate to determine the causes of deterioration of their activities, to develop measures to improve personnel management and, as a result, the financial condition of the enterprise.

\section{References}

1. Balanovska, T. I. (2017). Menedzhment personalu v APK Ukrainy. Kyiv, 19.

2. Kylyn, O. V., Tymchyshyn, O. V. (2018). Formation of personnel of the enterprise of the hotel business: domestic and foreign experience. Naukovyi visnyk Uzhhorodskoho natsionalnoho universytetu, 2, 20-24.

3. Marchenko, O. A., Samokish, A. O., Strebkova, K. M. (2018). Features of personnel management in the sphere of tourism and hotel and restaurant industry. Ekonomika ta upravlinnnia pidpryiemstvamy, 17, 169-173.
4. Ohiienko, N., Ohiienko, A., Melnyk, A. (2018). Management of personnel of enterprises of hotel-restaurant business. Naukovyi visnyk MNU imeni v. O. Sukhomlynskoho. Ekonomichni nauky, 2 (11), 56-62.

5. Falchenko, O. O., Yurieva, I. A., Mardus, N. Yu. (2018). Methods of personnel management in establishments of hotel-restaurant economy. Naukovyi visnyk MNU imeni v. O. Sukhomlynskoho. Ekonomichni nauky, 2 (11), 56-62.

6. The World Tourism Organization (UNWTO). Available at: https:// www.unwto.org Last accessed: 08.05.2021

7. Ochkurenko, D. A. (2019). Improvement of the personnel management system at the printing enterprise. Kyiv, 105. Available at: https://ela.kpi.ua/bitstream/123456789/28293/1/Ochkurenko_bakalavr.pdf Last accessed: 03.05.2021

8. Chen, W.-J., Cheng, H.-Y. (2012). Factors affecting the knowledge sharing attitude of hotel service personnel. International Journal of Hospitality Management, 31 (2), 468-476. doi: http:// doi.org/10.1016/j.ijhm.2011.07.005

9. Sean, V. (2010). Human resource management, ethical context, and personnel consequences: A commentary essay. Journal of Business Research, 63 (8), 908-910. doi: http://doi.org/10.1016/ j.jbusres.2009.02.029

10. Poiedintseva, V. V. (2014). Upravlinnia personalom na malykh ta serednikh pidpryiemstvakh. Kharkiv, 18.

11. Ksenofontova, Kh. Z. (2011). Kompetentsii upravlencheskogo personala: teoriia i metodologiia razvitiia. Moscow: Kreativnaia ekonomika, 184.

12. Udalov, A. (2016). Stymuliuvannia personalu. Personal-Miks, $1,12-15$.

13. Chobitok, V. I., Voloshchenko, A. V. (2015). Formation of personnel management in industrial enterprises: theoretical aspects. Visnyk ekonomiky transportu ta promyslovosti, 50, 313-318.

14. Bielik, V. D. (2014). Funktsionalnyi pidkhid do formuvannia systemy upravlinnia personalom pidpryiemstva. Visnyk Lvivskoi komertsiinoi akademii, 45, 54-57.

$\square$ Iryna Segeda, PhD, Senior Lecturer, Department of Tourism and Hospitality, O. M. Beketov National University of Urban Economy in Kharkiv, Ukraine, e-mail: Irina.segeda2006@gmail.com, ORCID: https://orcid.org/0000-0002-2364-4410

Larysa Obolentseva, Doctor of Economic Sciences, Professor, Department of Tourism and Hospitality, O. M. Beketov National University of Urban Economy in Kharkiv, Ukraine, ORCID: https:// orcid.org/0000-0001-7085-6902

Svitlana Aleksandrova, PhD, Associate Professor, Department of Tourism and Hospitality, O. M. Beketov National University of Urban Economy in Kharkiv, Ukraine, ORCID: https://orcid.org/ 0000-0001-9842-436X

$\triangle$ Corresponding author 